\title{
ATITUDES LINGUÍSTICAS DE ESTUDANTES CHINESES NO ENSINO SUPERIOR EM PORTUGAL.
}

\section{Angelo R. G. Ribeiro*, Juliana Bertucci.}

\section{Resumo}

Este trabalho é um recorte do projeto de iniciação científica desenvolvido durante a graduação sanduiche na Universidade de Aveiro, em Portugal, no período de agosto de 2016 a julho de 2017, sobre as atitudes linguísticas de estudantes chineses no ensino superior.

\section{Palavras-chave: \\ Atitudes Linguísitcas, estudantes chineses, percepção linguísitca.}

\section{Introdução}

O objetivo geral fora investigar as atitudes linguísticas de estudantes desta universidade, em relação às diferentes variedades da língua portuguesa presentes em seu contexto universitário e pessoal. Para isso, desenvolvemos um teste de atitudes linguísticas com 0 propósito de conhecer como as atitudes e as avaliações linguísticas interferem no processo de constituição da identidade de uma comunidade (por meio de sua língua). $O$ teste fora dividido em duas partes, a saber: "Parte A: Perfil social" e "Parte $B$ : Perguntas relacionadas às atitudes linguísticas". A parte B foi subdividida em seis blocos, todos compostos de perguntas fechadas em que contextualizávamos o informante em situações comunicativas específicas. Este trabalho constitui a apresentação do grupo 2, alunos chineses do Departamento de Línguas e Culturas da Universidade de Aveiro em Portugal, em que há 37 informantes, sendo 32 do sexo feminino e 5 do sexo masculino todos de nacionalidade chinesa.

\section{Resultados e Discussão}

As atitudes, ligadas às crenças, não são características inatas às pessoas, elas são formadas e aprendidas no processo de socialização (cf. BOTASSINI, 2015), por isso, os resultados dos nossos testes evidenciaram como os graduandos assumem e reconhecem certos usos linguísticos regionais. Como afirmam Giles, Ryan e Sebastian (1982), em uma sociedade, as diferenças de "poder" existentes entre grupos sociais podem ser observadas na variação linguística e nas atitudes para com essas variações. Além disso, os resultados obtidos permitiram-nos auxiliar e fomentar a reflexão acerca das atitudes linguísticas que podem trazer benefícios ao ensino e aprendizagem da língua portuguesa. No teste buscamos perceber a reação ao conhecimento da variação linguística do português, se isso é sentido e qual a avaliação dos informantes a respeito da recepção por parte dos ouvintes. De acordo com os dados, a maioria dos informantes percebem a diferença na maneira de falar português na Universidade e entre amigos. 92\% acreditam também que ambiente mais formal, Universidade, é o lugar em que se mais bem fala e o que é mais prejudicial falar errado. $68 \%$ reagem negativamente a um profissional que fale errado, é dizer que se o ouvinte entende que o uso da variante ou variedade do falante for incorreta conforme as suas concepções de língua irão avaliar o indivíduo como ruim. $38 \%$ dos informantes afirmam se sentirem constrangido por não falar o português como a maioria das pessoas ao seu redor, essa reação é incômoda ao falante estrangeiro, pois se sente deslocado e não integrado a comunidade linguística universitária.

\section{Conclusões}

Contudo podemos inferir que o grupo 2 reconhece as variedades da língua portuguesa ainda que intuitivamente e têm a crença que há um português melhor que outro. Essa crença pode ser entendida através da hipótese do intercâmbio linguístico, os informantes são chineses e estudam em Portugal e a Universidade é uma instituição formal de ensino, portanto, hipoteticamente, esse é o país da língua estudada, um lugar mais adequado para a formação e aprendizado do idioma. Vale salientar que os alunos são estudantes de Línguas e Culturas na Universidade de Aveiro o que pode condicionar essa crença por parte de uma identificação linguística dos ambientes: pais e instituição. Tais dados reforçam a hipótese que existe a crença de falar errado o português, embora entre amigos essa percepção linguística é irrelevante. O falar certo está condicionado a uma variedade, a uma norma convencionada, institucionalizada e prestigiada, enquanto as demais variedades recai a percepção de descrédito, marginalidade e preconceito.

\section{Agradecimentos}

A minha orientadora, Juliana Bertucci, à UFTM-Uberaba, a Capes, instituição de fomento, à Universidade de Aveiro e a todos as demais pessoas que me auxiliaram para a conclusão dessa Iniciação Cientifica.

BOTASSINI, Jacqueline Ortelan Maia. A Importância dos Estudos de Crenças e Atitudes para a Sociolinguística. Signum: Estud. Ling., Londrina, n. 18/1, p. 102-131, jun. 2015.

GILES, H.; RYAN, E. B.; SEBASTIAN, R. J. An integrative perspective for the study of attitudes toward language variation. In: GILES, H.; RYAN, E. B. (Eds.). Attitudes towards language variation: social and applied context. London: Edward Arnold, 1982. p. 1-19.1k 